\title{
One optometrist's personal experience with age-related macular degeneration (AMD) and nutritional supplementation
}

\author{
BY STUART RICHER, OD, PhD ${ }^{1} \&$ \\ ALBERT S LICUP, OD² \& \\ TERE PORTER, $O D^{3} \&$ \\ FREDERICK COLLISON, OD
}

\section{Introduction}

$\mathrm{A}_{\text {from the National Eve In- }}$ a result of recent findings stitute's Age-Related Eye Disease Study (AREDS) and the Veterans Lutein Antioxidant Supplementation Trial (LAST) Study, interventions for patients with atrophic age-related macular degeneration now include recommendations for dietary supplements in an effort to slow, halt or reverse the disease's progression. The AREDS formulation consists of $500 \mathrm{mg}$ vitamin C, 400IU vitamin E, $80 \mathrm{mg}$ zinc, $2 \mathrm{mg}$ copper and 15,000IU beta-carotene. ${ }^{1}$ LAST participants received $10 \mathrm{mg}$ lutein daily, or $10 \mathrm{mg}$ lutein plus a broad-spectrum formulation of antioxidants, vitamins and minerals. ${ }^{2}$ AREDS and LAST

\section{RÉSUMÉ}

Contexte : La dégénérescence maculaire liée à l'âge (DMLA) est la principale cause de cécité dans les sociétés occidentales vieillissantes et entraîne plus de 50 \% du total des incapacités visuelles aux ÉtatsUnis. Ce rapport décrit l'histoire d'un optométriste de 66 ans qui lutte avec succès contre la DMLA depuis 25 ans.

Rapport de cas : Acuité visuelle et série de photographies de la rétine de 1983 à 2009 à mesure que diverses modifications des habitudes alimentaires et des habitudes de vie non alimentaires ont été mises en œuvre. Après avoir commencé à prendre des suppléments nutritionnels à base de lutéine environ 15 ans après le diagnostic, l'optométriste a vu son acuité visuelle selon l'échelle de Snellen s'améliorer dans son œil droit pour passer de 20/40 à 20/25, combinée à une amélioration subjective de la distorsion, mais elle a éventuellement régressé à 20/70-20/80 accompagnée d'une augmentation de la métamorphopsie. Dans l'œil gauche, l'acuité visuelle de 20/30 au début s'est améliorée à 20/15 et est demeurée stable à 20/20 accompagnée d'une résolution complète de la métamorphopsie et d'une résolution quasi complète du scotome parafovéal. Des photographies du fond de l'œil démontrent une réduction du dénombrement des drusens mous et durs au fil du temps dans chaque rétine et une repigmentation parafovéale possible de zones atrophiques après l'ajout ultérieur de zéaxanthine à plus forte dose.

Conclusions : La DMLA est une maladie qui répond à la nutrition. Le caroténoïde, la lutéine et la zéaxanthine semblent constituer des éléments thérapeutiques particulièrement robustes de formulations de suppléments nutritionnels.

Mots clés : Dégénérescence maculaire liée à l'âge, lutéine, zéaxanthine.
1 Director, Ocular Preventive MedicineEye Clinic, DVA Medical Center North Chicago, IL

2 Staff Optometrist, Naval Health Clinic Great Lakes, Great Lakes, IL

3 Optometrist, Norway, ME

4 Optometrist, The Chicago Lighthouse for People Who Are Blind or Visually Impaired, Chicago, IL

formulations both decreased the vision loss in patients with moderate and severe AMD, although long-term risk reduction with lutein could not be evaluated due to the small sample size and short timeframe of the LAST study. Intervention with lutein in LAST also led to improved vision in patients with mild, moderate and severe forms of AMD, presumably by increasing macular pigment optical density (MPOD). ${ }^{2}$ More recent studies demonstrate the utility of lutein and zeaxanthin supplementation in the fight against atrophic AMD, using such methods as $\mathrm{mfERG},{ }^{3}$ fundus autofluorescence, ${ }^{4}$ and heterochromatic flicker photometry. ${ }^{5}$ The Zeaxanthin and Visual Function Study compared lutein to zeaxanthin, to lutein plus zeaxanthin supplementation using kinetic visual fields, foveal shape discrimination and heterochromatic flicker photometry. ${ }^{6}$ 


\section{Case Report}

\section{An OD's Struggle}

A then 41-year old Caucasian male optometrist (one of this report's authors, TP) was diagnosed with atrophic AMD in 1983 and initiated a plethora of over-thecounter supplements, including the original pre-lutein Bausch \& Lomb Ocuvite and Ocuvite Extra, Alcon ICAPS and ICAPS Plus, vitamin E, rose hip and Centrum. Baseline fundus photos taken in 1983 (Figure 1a) and 1988 (Figure 1b) demonstrated an increasing number and size of drusen over this five-year period despite this aggressive dietary supplement regimen. During the next 10 years, TP continued to monitor the disease and to take the supplements in an effort to slow disease progression.

In September 1997 at the age of 55, TP reported the development of metamorphopsia OU and a parafoveal scotoma was discovered on automated perimetry OS (not shown). Photos taken in 1998 demonstrated numerous intermediate-sized, and some large, soft, confluent drusen bilaterally (Figure 1c). During a consultation with an ophthalmologist in 1998, TP was told he may not be able to practice optometry in one-to-two years based on his fundus findings. The metamorphopsia he reported was accompanied by a reduction in visual acuity that appeared to support the ophthalmologist's contention. Visual acuity decreased from 20/20 each eye to 20/40 OD, $20 / 30$ OS. What makes this case compelling is serial photographic
Background: Age-related macular degeneration (AMD) is the leading cause of blindness in ageing western societies and accounts for greater than $50 \%$ of all US visual disability. This report describes the 25-year history of a 66-year-old optometrist who has successfully endured AMD.

Case Report: Visual acuity and serial retinal photographs from 1983 to 2009 as various nutritional modalities and non-dietary lifestyle changes were introduced. After starting lutein-based nutritional supplements beginning at approximately 15 years from diagnosis, the optometrist's Snellen visual acuity improved in his right eye from $20 / 40$ to 20/25 with a subjective improvement in distortion, but eventually regressed to 20/70-20/80 with some

\section{ABSTRACT}

increase in metamorphopsia. The left eye, initially $20 / 30$, improved to 20/15 and has remained stable at 20/20 with complete resolution of metamorphopsia and near complete resolution of a parafoveal scotoma. Fundus photographs demonstrate a reduction in soft and hard drusen count over time in each retina and possible parafoveal repigmentation of atrophic areas with later addition of higher dose zeaxanthin

Conclusions: AMD is a nutritionresponsive disease. The carotenoids, lutein and zeaxanthin appear to be particularly robust therapeutic components of nutritional supplement formulations.

Key words: age-related macular degeneration, lutein, zeaxanthin

supplement, his visual acuity improved from $20 / 40$ to $20 / 25$ OD and from $20 / 30$ to $20 / 15$ OS. A year later, TP no longer noticed metamorphopsia OU and the scotoma OS had markedly decreased in size. There were also visible salutary changes in his retinal images with respect to number and size of drusen (Figures 1c-1f).

TP stated his night vision was never affected by the atrophic AMD. Neither did he feel that his ability to practice optometry was ever jeopardized. Specifically, he did not need to change the lighting in his examination rooms, nor did he need to modify day-to-day procedures, such as performing direct ophthalmoscopy.

In November 2003, TP added an omega-3 supplement to his NSI OcuPower regimen after reading 
about the beneficial effects of essential fatty acids in slowing AMD progression. ${ }^{7} \mathrm{He}$ also started taking a mitochondrial support supplement, called Phototrop, containing $10 \mathrm{mg}$ coenzymeQ10, 390 mg omega-3 and $100 \mathrm{mg}$ acetyl 1-carnitine. Phototrop's combination was shown to improve visual functioning in a clinical research study. ${ }^{8,9}$

Bolstered by his visual and funduscopic improvements, TP added EyePromise, containing high-dose zeaxanthin, to round out his supplementation regimen in May 2004 after emerging research suggested that this foveal carotenoid may play an important role in central macular health., ${ }^{4,5}$, Photos taken in August 2005 (Figure 1g) and February 2008 (Figure 1 h) demonstrated a dramatic decrease in drusen $\mathrm{OU}$, possibly attributed to his regimen of NSI OcuPower, EyePromise, Phototrop and omega-3 supplements (Table 2). The drusen were smaller and fainter, and an encouraging "re-pigmentation of the atrophic areas" was noted by TP when evaluating his own fundus photos. Unfortunately, visual acuity in his right eye regressed to $20 / 40$. The left eye however, remained stable at 20/15. Strikingly, no metamorphopsia was present.

The latest photos, from February 2009 (Figure 1g), 11 years after adding carotenoids, show further significant reduction of pre-existing drusen, with some persistent geographic atrophy now affecting the fovea in the right eye. TP noted increasing metamorphopsia OD, but no metamorphopsia OS,

Figure 1 - $(\mathrm{a}-\mathrm{c})$

Baseline bilateral fundus photographs of optometrist, TP, taken in 1983 (1a, age 41)

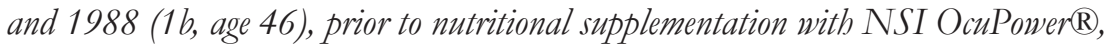

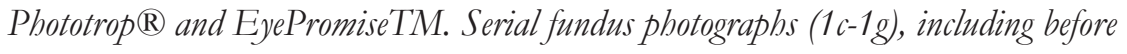
the start of lutein (1c) and zeaxanthin (1e) based nutritional supplementation.

\section{RIGHT EYE}

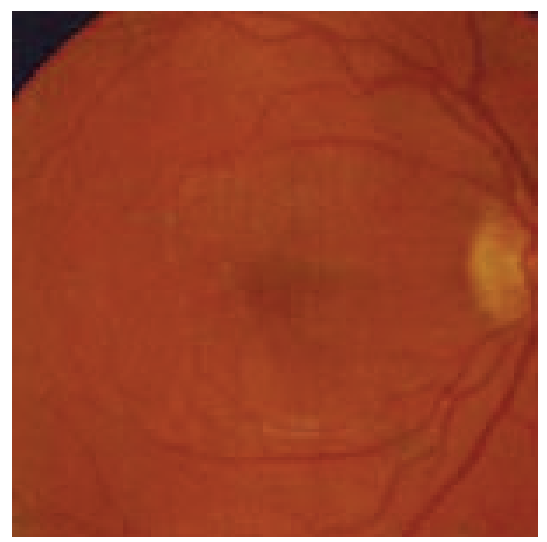

1a : 1983 - First diagnosis

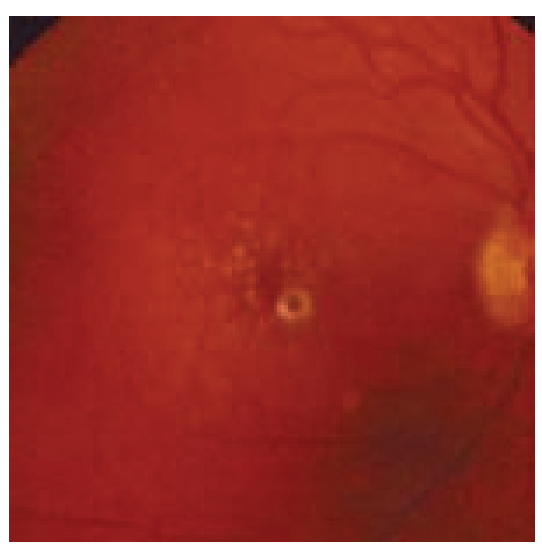

1b : $1988-5$ years later

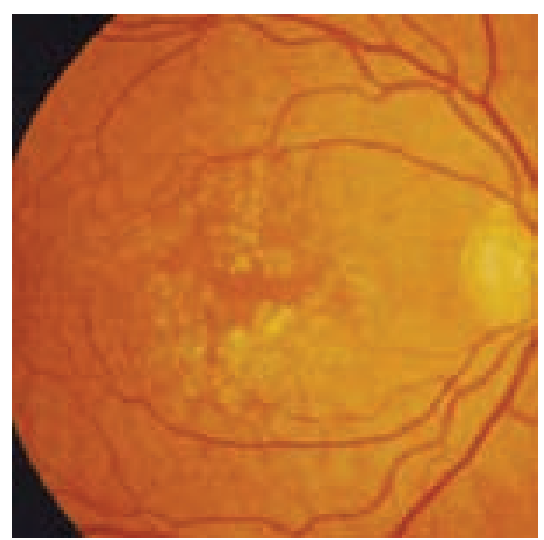

1c:1/23/98 -- Carotenoids
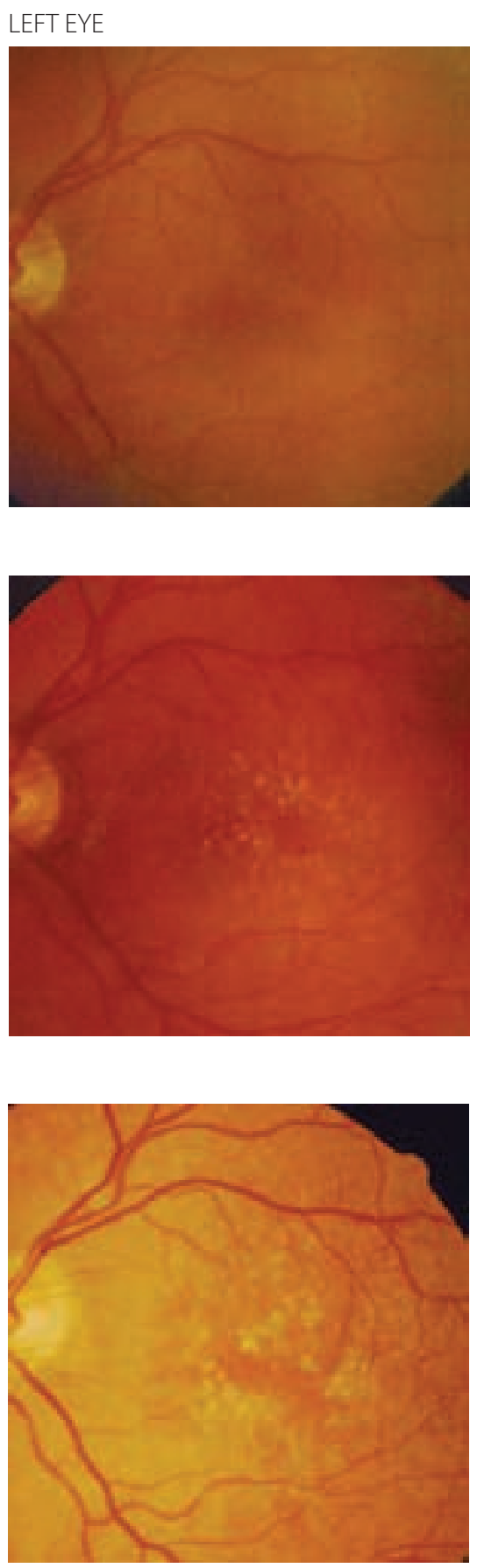
with acuities of 20/70- OD and 20/20 OS. No significant cataract or other media opacity was found at the February 2009 visit.
Other dietary \& non-dietary lifestyle modifications

TP's nutritional regimen didn't stop with the addition of the supplements noted above. In 1998

Figure $1-(d-e)$

\section{RIGHTEYE}

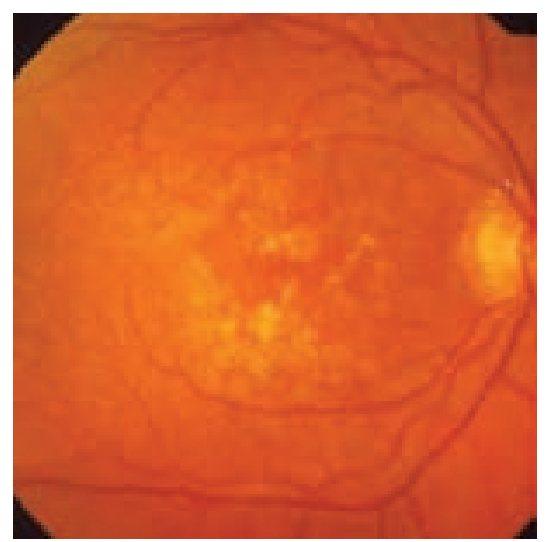

$1 \mathrm{~d}: 1 / 26 / 00$

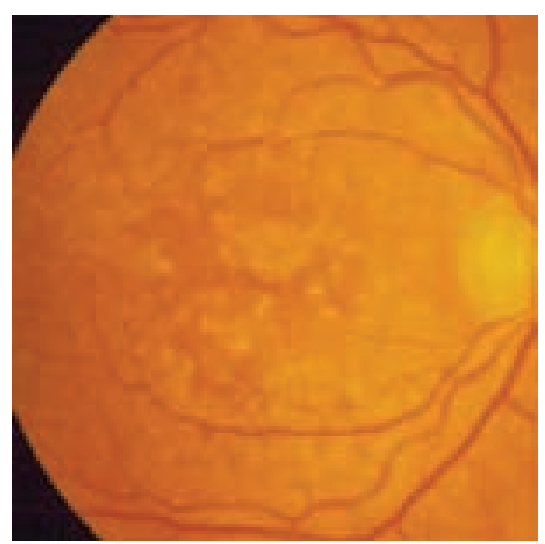

$1 \mathrm{e}: 8 / 5 / 2003$

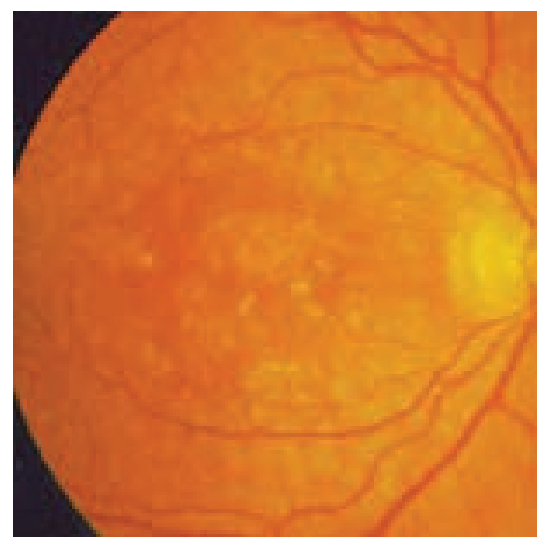

1f: $8 / 18 / 05$
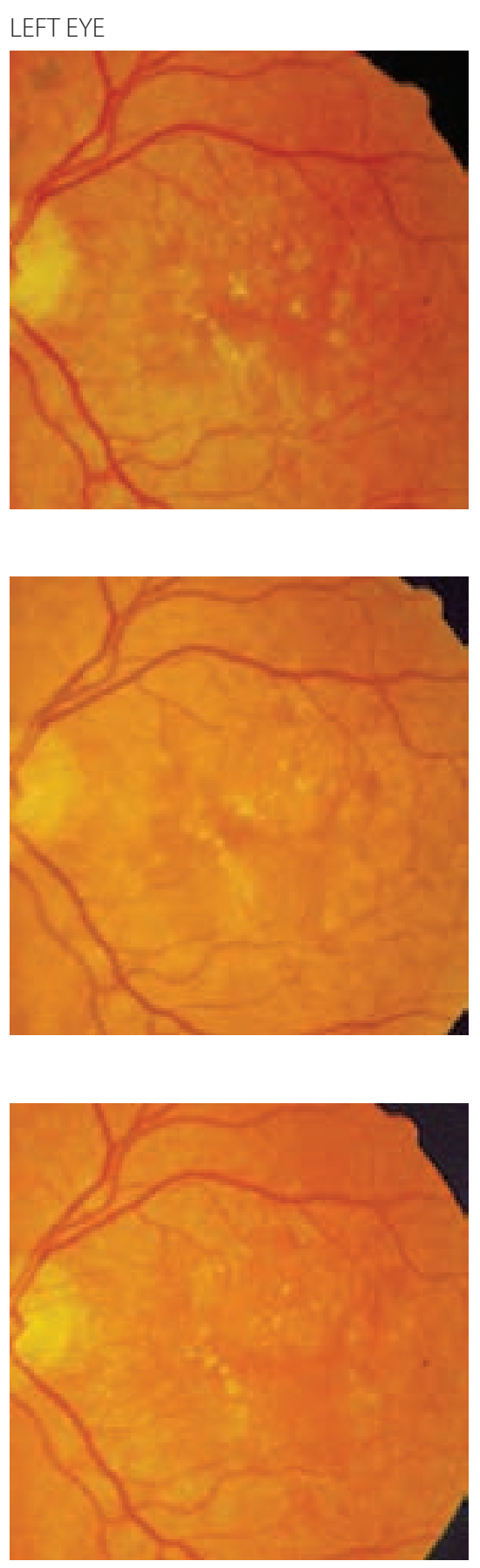

he began eating wolfberries (goji berries), another source of zeaxanthin, daily. He also consumed more kale, collard greens, turnip greens, spinach, and mustard greens - all prime sources of lutein to elevate his macular pigment optical density..$^{10}$ In December 2003, he added a combination bioflavonoid capsule, containing grape seed, green tea and red wine extract taken twice daily after reading evidence that these components may contribute to lower cholesterol levels and better retinal pigment epithelial (RPE) function, which in turn may slow the progression of AMD. ${ }^{11}$

Additionally, TP increased his intake of oily fish, such as salmon and sardines, to raise his omega-3 level. He has avoided overcooked foods, especially overcooked vegetables. ${ }^{12}$ He has limited intake of commercial hydrogenated or partially-hydrogenated oils, known to dramatically increase the risk of cardiovascular disease ${ }^{13}$ and associated with late AMD. ${ }^{14}$

TP is a non-smoker, which is beneficial in light of the Beaver Dam Eye Study in the US, the Blue Mountain Eye Study in Australia, and Rotterdam Study in the Netherlands, which all found a significant association between smoking and AMD. ${ }^{11} \mathrm{He}$ controls his weight through routine exercise, which is also important because lower body mass index (BMI) and increased physical activity have been shown to decrease the rate of progression to advanced forms of AMD. ${ }^{15} \mathrm{TP}$ wears ultraviolet/blue-light blocking sunglasses to protect his eyes when outdoors. ${ }^{16,17}$ 


\section{Discussion}

We have presented in a sense the un-natural/natural history of AMD in a practicing optometrist over a 25 -year period. Serial retinal photos, with introduction of carotenoids in 1998, indicate a progressive decrease in the number and size of drusen and atrophic areas in both of TP's retinas. Despite a recent increase in metamorphopsia and decrease in acuity OD, TP's visual acuity has remained stable OS at 20/20, and his central visual fields remain largely intact. TP only recently retired from his private optometric practice in Norway, Maine, where he performed comprehensive eye care for 44 years until January 2010, when he retired at the age of 67.

When originally released, NSI OcuPower contained only $1 \mathrm{mg}$ of lutein. Lycopene was added in the second formulation. In the third formulation, lutein concentration was increased to $10 \mathrm{mg}$. In the fourth formulation $500 \mathrm{mcg}$ of zeaxanthin was introduced. This is the version of NSI OcuPower (Table 1) that was evaluated during the LAST study. ${ }^{2}$ A newer formulation is now available, now under the name NSI Synergy OcuPower Advanced. Carotenoids appear to be specifically important in this case. Lutein, an oxy-carotenoid, is believed to protect the macula by blocking blue light which helps to improve contrast sensitivity in certain situations ${ }^{18,19}$, while reducing glare disability. ${ }^{20}$ It is believed to function as an antioxidant, improving photo-stress recovery time and

Figure 1 - ( g)

RIGHTEYE

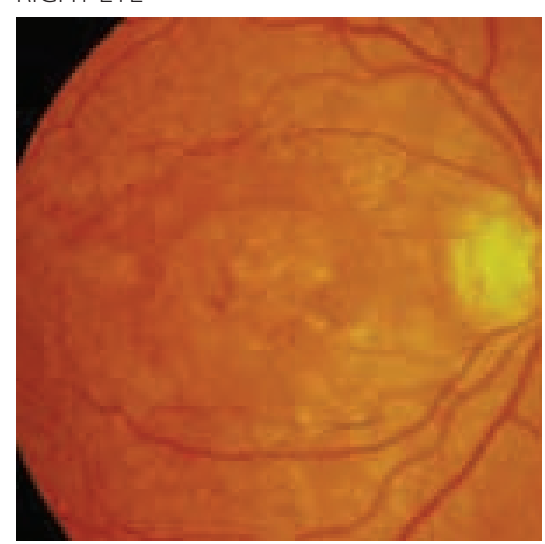

$1 \mathrm{~g}: \operatorname{1g}$ 02/06/09 (11 years)

providing structural integrity to photoreceptors by its conversion to meso-zeaxanthin. ${ }^{10}$ Patients with AMD have less macular lutein than those without the disease, as determined through autopsy and in vivo measurements, and macular lutein decreases with aging, smoking and obesity - the three major risk factors for AMD. ${ }^{11,15}$ Using heterochromic flicker photometry, the LAST study demonstrated that lutein supplementation increased mean MPOD by $36 \%$ in the study group that received $10 \mathrm{mg}$ lutein only, and by $43 \%$ in the group receiving the multi-nutrient NSI OcuPower supplement. Snellen visual acuity and contrast sensitivity also improved statistically. Additionally, some study participants even experienced a subjective decrease in Amsler grid metamorphopsia and their scotoma(s). ${ }^{2}$

The authors of this paper conclude that future optometry practice should include some rudimentary measurement of
LEFT EYE

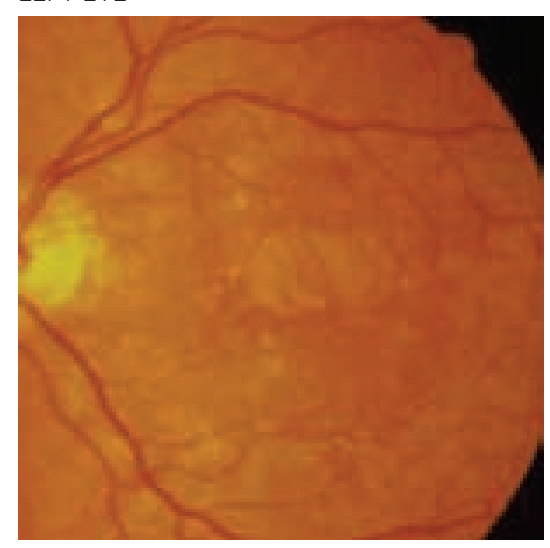

glare recovery (in seconds) as well as some measure of low contrast vision assessment, i.e. $10 \%$ low contrast screening evaluation to assess photoreceptor/RPE health. In this case, such data would have provided a metric for following subjective reports and more precisely defined the results of multiple therapeutic interventions. Notably TP had AMD at the early age of 41. Glare recovery and contrast sensitivity assessment would be particularly useful for all patients older than for example, 50 years of age. Unfortunately in this case, only traditional Snellen visual acuity (circa 1862) and Amsler grid (1895) are available. Nonetheless, although we cannot prove causality with a single case report, the retinal photographs presented within this report appear to demonstrate a dynamic disease process amenable to nutritional intervention. 
Table 1 - Components of lutein-based multivitamin, multi-mineral formulation in

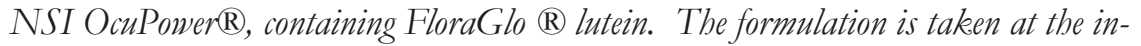
dicated dose of three times per day. The formulation has changed since the LAST study and the name is now NSI Synergy Ocupower Advance ${ }^{\circledR}$ (www.Vitacost.com).

\begin{tabular}{|c|c|}
\hline \multicolumn{2}{|l|}{ Nutraceutical Sciences Institute (NSI) OcuPower } \\
\hline \multicolumn{2}{|l|}{ Supplement facts: Serving size - 6 capsules (taken TID) } \\
\hline Component & Full daily dose \\
\hline $\begin{array}{l}\text { Pro-vitamin A (as natural carotenoids: beta carotene, alpha carotene, } \\
\text { lutein, zeaxanthin, cryptoxanthin) (Betatene) }\end{array}$ & $4,900 \mathrm{IU}$ \\
\hline Vitamin A (as palmitate) & $100 \mathrm{IU}$ \\
\hline Vitamin C (as calcium ascorbate) (Ester-C MV) & $250 \mathrm{mg}$ \\
\hline Vitamin D3 (as cholecalciferol) & $700 \mathrm{mg}$ \\
\hline $\begin{array}{l}\text { Mixed vitamin E (as d-alpha tocopherol succinate and mixed } \\
\text { tocopherols) }\end{array}$ & $210 \mathrm{IU}$ \\
\hline Vitamin B1 (thiamine $\mathrm{HCl}$ ) & $20 \mathrm{mg}$ \\
\hline Vitamin B2 (riboflavin) & $10 \mathrm{mg}$ \\
\hline Vitamin B3 (niacinamide) & $20 \mathrm{mg}$ \\
\hline Vitamin B6 (pyridoxine $\mathrm{HCl}$ ) & $20 \mathrm{mg}$ \\
\hline Folic acid (as folacin) & $1 \mathrm{mg}(1,000 \mathrm{mcg})$ \\
\hline Vitamin B12 (methylcobalamin) & $500 \mathrm{mcg}$ \\
\hline Biotin & $500 \mathrm{mcg}$ \\
\hline Vitamin B5 (pantothenic acid) & $20 \mathrm{mg}$ \\
\hline Calcium (ascorbate, Ester-C MV) & $25 \mathrm{mg}$ \\
\hline Magnesium (oxide) & $100 \mathrm{mg}$ \\
\hline Zinc (as L-methionine) (L-OptiZinc) & $25 \mathrm{mg}$ \\
\hline Selenium (selenomethionine) & $200 \mathrm{mcg}$ \\
\hline Manganese (as amino acid chelate) & $2 \mathrm{mg}$ \\
\hline Copper (as amino acid chelate) & $1 \mathrm{mg}$ \\
\hline Chromium (chromium polynicotinate) (ChromeMate) & $400 \mathrm{mcg}$ \\
\hline Molybdenum (as amino acid chelate) & $150 \mathrm{mcg}$ \\
\hline Bilberry extract (standardized to 25\% anthocyanosides) (fruit) & $40 \mathrm{mg}$ \\
\hline $\begin{array}{l}\text { Lycopene (from } 120 \text { mg standardized 5\% Lyc-O-Mato lycopene } \\
\text { extract) (fruit) }\end{array}$ & $6 \mathrm{mg}$ \\
\hline $\begin{array}{l}\text { Lutein (from } 200 \text { mg standardized 5\% FloraGLO Lutein extract) } \\
\text { (marigold flower) }\end{array}$ & $10 \mathrm{mg}$ \\
\hline $\begin{array}{l}\text { Zeaxanthin (from } 200 \text { mg standardized .22\% FloraGLO Lutein extract) } \\
\text { (marigold flower) }\end{array}$ & $500 \mathrm{mcg}$ \\
\hline Alpha lipoic acid & $150 \mathrm{mg}$ \\
\hline Bioflavonoid (as quercetin) & 100 mg \\
\hline Bioflavonoid (as rutin) & $10 \mathrm{mg}$ \\
\hline Bioflavonoid (citrus biocomplex standardized to $50 \%$ ) & $10 \mathrm{mg}$ \\
\hline Black pepper (Peper nigrum) (fruit extract) (BioPerine) & $5 \mathrm{mg}$ \\
\hline $\begin{array}{l}\text { Ginko biloba (ginkgoaceae) (leaves) (standardized } 24 \% \text { ginko flavon } \\
\text { glycosides, } 6 \% \text { terpene lactones) }\end{array}$ & $120 \mathrm{mg}$ \\
\hline L-Taurine & 100 mg \\
\hline
\end{tabular}

Other ingredients: Kosher gelatin (capsule), cellulose, silica magnesium stearate

\section{Acknowledgements}

We are indebted to Tere Porter, OD, for carefully documenting his affliction. Special thanks to Vitacost.com (Boyton Beach, FL), Kemin Health, Inc. FloraGlo ® lutein (Des Moines,

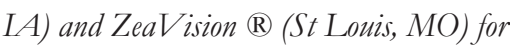
their expertise in supplying Dr. Porter with information and encouragement. The authors also acknowledge the Captain James A Lovell FHCC / Department of Veterans Affairs Medical Center, North Chicago, IL, Naval Health Clinic Great Lakes, Great Lakes, IL, Department of Family \& Preventive Medicine at Rosalind Franklin University of Medicine \& Science, North Chicago, IL.

\section{References}

1. Age-Related Eye Disease Study Research Group. A randomized, placebocontrolled, clinical trial of high-dose supplementation with vitamins $\mathrm{C}$ and $\mathrm{E}$ and beta carotene for age-related cataract and vision loss: AREDS report no. 9. Arch Ophthalmol 2001; 119(10):1439-52.

2. Richer S, Stiles W, Statkute L, et al. Double-masked, placebo-controlled, randomized trial of lutein and antioxidant supplementation in the intervention of atrophic age-related macular degeneration: the Veterans LAST study [Lutein Antioxidant Supplementation Trial]. Optometry 2004 April; 75(4):216-30.

3. Parisi V, Tedeschi M, Gallinaro G, et al.; CARMIS Study Group. Carotenoids and antioxidants in age-related maculopathy italian study: multifocal electroretinogram modifications after 1 year. Ophthalmology. 2008;115(2):324-333.e2.

4. Trieschmann M, Beatty S, Nolan JM, Hense HW, et al. Changes in macular pigment optical density and serum concentrations of its constituent carotenoids following supplemental lutein and zeaxanthin: the LUNA study. Exp Eye Res. 2007;84(4):718-28.

5. Schalch W, Cohn W, Barker FM, et al. Xanthophyll accumulation in the human retina during supplementation with lutein or zeaxanthin - the LUXEA (LUtein Xanthophyll Eye Accumulation) study.Arch Biochem Biophys. 2007 15;458(2):128-35. 
Table 2 - Visual and ophthalmic timeline for TP.

\begin{tabular}{|c|c|c|c|c|}
\hline $\begin{array}{l}\text { DATE } \\
(\mathrm{d} / \mathrm{m} / \mathrm{y})\end{array}$ & EVENT & FUNDUS & $\begin{array}{l}\text { VISUAL } \\
\text { ACUITY }\end{array}$ & $\begin{array}{c}\text { META- } \\
\text { MORPHOPSIA }\end{array}$ \\
\hline 1983 & $\begin{array}{l}\text { TP diagnosed with atrophic } \\
\text { AMD; fundus photo taken }\end{array}$ & $\begin{array}{l}\text { Scattered mild } \\
\text { drusen OU }\end{array}$ & $20 / 20$ & None \\
\hline 1983-1987 & $\begin{array}{l}\text { TP taking Ocuvite, Ocuvite Extra, } \\
\text { ICAPS, ICAPS Plus, vitamin E, rose } \\
\text { hip and Centrum }\end{array}$ & NC & NC & NC \\
\hline 1988 & Fundus photo taken & $\begin{array}{l}\text { Increasing } \\
\text { drusen OU }\end{array}$ & NC & NC \\
\hline 9/1997 & $\begin{array}{l}\text { TP performs HVF and finds small } \\
\text { parafoveal scotoma OS }\end{array}$ & NC & NC & OD, OS \\
\hline $1 / 23 / 1998$ & Baseline fundus photos OU & $\begin{array}{l}\text { Large drusen } \\
\text { and pigment } \\
\text { changes OU }\end{array}$ & NC & NC \\
\hline 2/1998 & $\begin{array}{l}\text { TP discusses fundus photos with } \\
\text { ophthalmologist, begins taking } \\
\text { OcuPower and d/c's all other } \\
\text { supplements. }\end{array}$ & NC & $\begin{array}{l}\text { 20/40 OD, } \\
\text { 20/30 OS }\end{array}$ & NC \\
\hline $1 / 26 / 2000$ & 2-year fundus photo OU & $\begin{array}{l}\text { Decreasing } \\
\text { size and } \\
\text { number of } \\
\text { drusen OU }\end{array}$ & $\begin{array}{l}\text { 20/20 OD, } \\
\text { 20/15 OS }\end{array}$ & None \\
\hline $8 / 3 / 2000$ & 2.5-year fundus photo & NC & NC & NC \\
\hline $8 / 5 / 2003$ & 5.5-year fundus photo & NC & NC & NC \\
\hline $11 / 2003$ & $\begin{array}{l}\text { TP begins taking Phototrop and } \\
\text { Omega-3 supplement. }\end{array}$ & NC & NC & NC \\
\hline $12 / 2003$ & $\begin{array}{l}\text { TP begins taking bioflavinoid } \\
\text { capsule. }\end{array}$ & NC & NC & NC \\
\hline $5 / 2004$ & TP begins taking EyePromise. & NC & NC & NC \\
\hline $8 / 18 / 2005$ & 7.5-year fundus photo & $\begin{array}{l}\text { Decrease in } \\
\text { drusen OU }\end{array}$ & $\begin{array}{l}\text { 20/40 OD, } \\
20 / 15 \text { OS }\end{array}$ & NC \\
\hline $2 / 06 / 2009$ & 11-year fundus photo & $\begin{array}{l}\text { Fewer drusen, } \\
\text { more } \\
\text { depigment- } \\
\text { ation OU }\end{array}$ & $\begin{array}{l}\text { 20/70-20/80 } \\
\text { OD, } \\
20 / 20 \text { OS }\end{array}$ & $\begin{array}{l}\text { Increasing } \\
\text { meta- } \\
\text { morphopsia } \\
\text { OD }\end{array}$ \\
\hline
\end{tabular}

6. Richer SP, Stiles WR, Levin MR, et al. The Zeaxanthin and Visual Function Study in Atrophic Age Related Macular Degeneration (ZVF-FDA IND \#78,973) - MP and Foveal Shape Discrimination Data. Invest Ophthalmol Vis Sci. 2010: ARVO E-Abstract 510.

7. SanGiovanni JP, Chew EY, Clemons TE, et al. The relationship of dietary lipid intake and age-related macular degeneration in a case-control study: AREDS Report No. 20. Arch Ophthalmol 2007;125(5):671-9
8. Feher J, Papale A, Mannino G, et al. Mitotropic Compounds for the treatment of age-related macular degeneration. Ophthalmologica. 2003;217:351-357.

9. Feher J, Kovacs B, Kovacs I, et al. Improvement of visual functions, and fundus alterations in early age-related macular degeneration treated with a combination of acetyl-L-carnitine, n-3 fatty acids, and coenzyme Q10. Ophthalmologica 2005;219:154-166.

10. Bernstein PS, Delori FC, Richer S, et al. The value of measurement of macular carotenoid pigment optical densities and distributions in age-related macular degeneration and other retinal disorders. Vision Res. 2010;50(7):716-28.

11. Tomany SC, Wang JJ, Van Leeuwen R. et al. Risk factors for incident age-related macular degeneration: pooled findings from 3 continents. Ophthalmology. 2004;111(7):1280-7.

12. Maiani G, Periago Castón MJ, Catasta G, et al. Carotenoids: Actual knowledge on food sources, intakes, stability and bioavailability and their protective role in humans. Mol Nutr Food Res. 2009;53(S2):S194-S218.

13. Teegala S, Willett W, Mozaffarian D. Consumption and health effects of trans fatty acids: A review. J AOAC Int. 2009;92(5), 1250-1257.

14. Chong EW, Robman LD, Simpson JA, et al. Fat consumption and its association with age-related macular degeneration. Arch Ophthalmol. 2009;127(5):674-680.

15. Seddon JM, Cote J, Davis N, et al. Progression of age-related macular degeneration: association with body mass index, waist circumference, and waist-hip ratio. Arch Ophthalmol. 2003; 121(6):785-92.

16. Kernt M, Neubauer AS, Liegl R, et al. Cytoprotective effects of a blue light-filtering intraocular lens on human retinal pigment epithelium by reducing phototoxic effects on vascular endothelial growth factor-alpha, Bax, and $\mathrm{Bcl}-2$ expression. Cataract Refract Surg. 2009;35(2):354-62.

17. Mukai K, Matsushima H, Sawano $\mathrm{M}$, et al. Photoprotective effect of yellow-tinted intraocular lenses. Jpn J Ophthalmol. 2009;53(1):47-51.

18. Wolffsohn JS, Cochrane AL, Khoo H, et al. Contrast is enhanced by yellow lenses because of selective reduction of short-wavelength light. Optom Vis Sci. 2000;77(2):73-81.

19. de Fez MD, Luque MJ, Viqueira V. Enhancement of contrast sensitivity and losses of chromatic discrimination with tinted lenses. Optom Vis Sci. 2002;79(9):590-7.

20. Stringham JM, Hammond BR. Macular pigment and visual performance under glare conditions. Optom Vis Sci.2008;85(2):82-8. 